\title{
Félagslegar og samfélagslegar afleiðingar tanntaps, verkja vegna kjálkaliðskvilla (tmd) og viðeigandi meðferð
}

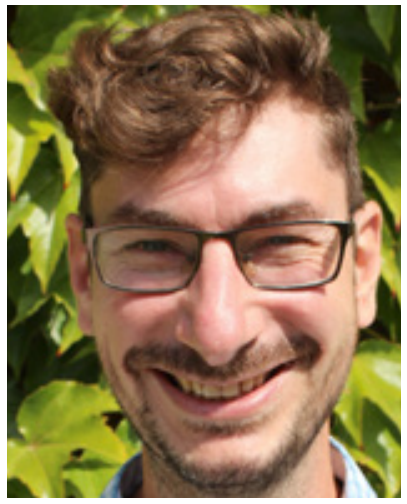

\author{
ESBEN BOESKOV ØZHAYAT DR.ODONT, PH.D. DÓSENT, SVIĐ SAMFÉLAGSTANNLÆEKNINGA, TANNLAKKADEILD \\ KAUPMANNAHAFNARHÁSKÓLA, DANMÖRK \\ EWA CARIN EKBERG ODONT. DD, SVIĐ ANDLITSVERKJA OG BITLÆKNINGA, TANNLAEKNADEILD, HÁSKÓLINN Í \\ MALMÖ, SVÍPJÓĐ
}

TENGILIĐUR: ESBEN BOESKOV ØZHAYAT, NØRRE ALLE 20, 2200 KAUPMANNAHÖFN N, DANMÖRK

eboz@sund.ku.dk

SAMPYKKT AF RITSTJÓRN PEMAVERKEFNIS TIL BIRTINGAR 25. MARS 2020

TANNLAEKNABLAĐIĐ 2020; 38: 73-79

doi: 10.33112/tann.38.1.8

\section{ÁGRIP}

Slæm munnheilsa, t.d. tanntap og verkir vegna kjálkaliðskvilla (TMD), getur haft mikil áhrif á lífsgæði og félagsleg tengsl einstaklinga. pessar einstaklingsbundnu afleiðingar geta að sama skapi haft áhrif á samfélagið, par sem slæm munnheilsa getur leitt til versnunar á almennu heilsufari og aukið kostnað í heilbrigðiskerfinu, meiri fjarvistum frá vinnu og atvinnuleysi. Ójöfnuður er stór áskorun pegar kemur að tanntapi og bágborin tannheilsa er algengari hjá félagslega viðkvæmum einstaklingum en hjá öðrum. Pessi félagslegi og hagræni ójöfnuður er minna áberandi hvað varðar TMD verki, en par er algengi mun meira hjá konum. Hjá einstaklingum í viðkvæmri félagslegri stöðu getur fremur einföld og inngrips lítil meðferð með tanngervum verið góður meðferðarkostur og ýmislegt bendir til pess að enduruppbygging tanna geti ýtt undir félagslega endurhæfingu. Hvað varðar TMD verki er mælt með meðferð án inngrips, s.s. fræðslu, góðri sjálfsumhirðu, hugrænni atferlismeðferð, teygjum og bitskinnum.

Lykilorð: Munnheilsa, lífsgæði, tannmissir, verkur í andliti, félagslegir og hagrænir pættir

\section{Inngangur}

Aukinn skilningur á pví að slæm munnheilsa og meðferð við henni geti haft mikil áhrif á líf einstaklings hefur orðið til pess að nú er meira horft til sjónarmiðs hans með pví að meta lífsgæði tengd munnheilsu (OHRQoL, oral health related quality of life). Munnheilsa nær pannig ekki aðeins til ástands í munnholi, heldur einnig til lífsgæða hans, p.m.t. líkamlegrar, sálrænnar og félagslegrar virkni og velferðar án verkja (1). Auk afleiðinga fyrir hvern einstakling er hugsanlegt að einnig sé um að ræða samfélagslegar afleiðingar. Í pessari grein er notast við vísindarýni og sjúklingatilfelli til að skoða sérstaklega tanntap og kjálkaliðskvilla (TMD). Hér verður fjallað um áhrif á lífsgæði, mögulegan ójöfnuð og samfélagslegan kostnað sem tengist slíku ástandi og viðeigandi inngripi (Mynd 1). 

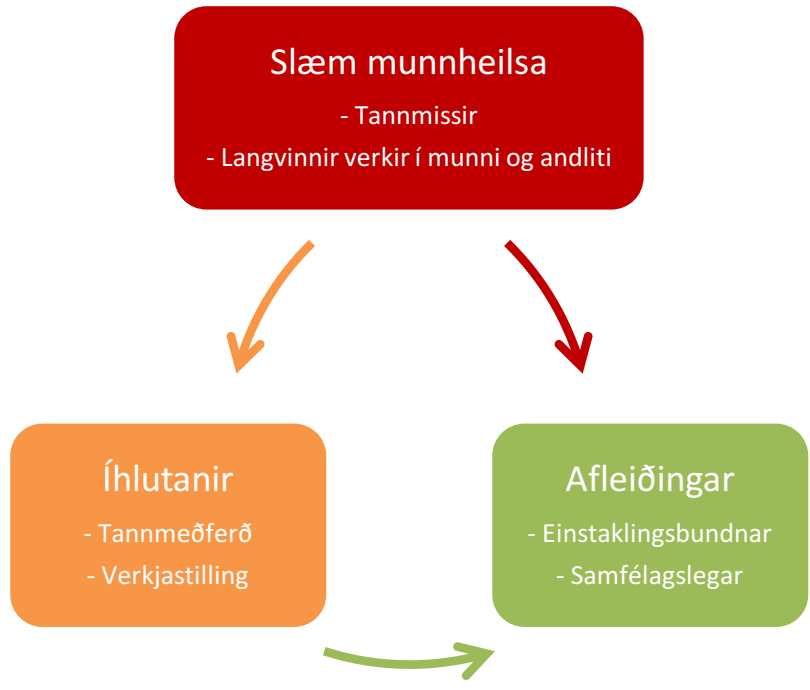

Mynd 1. Likan af tengslum milli slakrar munnheilsu og afleiðinga hennar, með sérstakri áherslu á tanntap og langvinna verki i munni og andliti.

Figure 1. Model of the connection between oral health and consequences hereof specified for the conditions tooth loss and chronic orofacial pain.

\section{Tanntap}

Niðurstöður rannsókna á áhrifum tanntaps sýna að pað dregur oft úr lífsgæðum og mikið tap, einkum á framtönnum, hafi enn meiri áhrif (2-4). Megináhrifin eru á útlit og tyggingu, sem veldur einkum félagslegum vandamálum (5). Sumar rannsóknir hafa sýnt fram á að tanntap skerði bæði sjálfstraust og félagslega stöðu (3). Áhrif tanntaps eru hins vegar afar einstaklingsbundin (6). Sem dæmi má nefna að sjúklingur á Mynd 2 nefndi ekki útlitsáhrifin, pví margir samstarfsfélaga hans voru einnig með slæma munnheilsu og að hans mati voru slæmar tennur hluti af sjálfsmynd hans sem "verkamanns". Ákveðin mörk virðast vera til staðar hjá flestum sjúklingum varðandi tannmissi. Eftir að farið er yfir pessi mörk finnst sjúklingnum tannmissirinn ekki ásættanlegur, annaðhvort vegna umfangs hans eða vegna staðsetningar peirra tanna sem hann hefur misst (4). Par sem pessi mörk eru ólík hjá sjúklingum getum við ekki sagt til um hvenær farið er yfir pau, sem aftur gerir tannlæknum erfiðara fyrir að ákveða hvenær pörf er á meðferð. Í pessu sambandi hafa rannsóknir sýnt að hefðbundnir klínískir mælikvarðar, s.s. fjöldi og staðsetning tapaðra tanna, eru gjarnan ekki bestu mælikvarðarnir á stöðu sjúklingsins (6) heldur parf að taka tillit til annarra áhrifapátta, s.s. persónugerðar sjúklingsins (7).

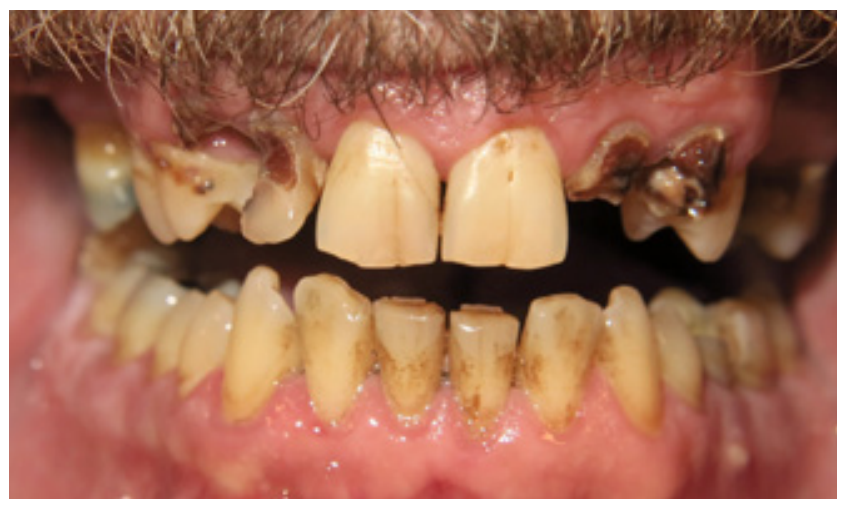

Mynd 2. Einstaklingsbundin áhrif. 49 ára karl óskar eftir tannlæknismeðferð, segir pað stafi ekki af útliti pví hann sé "verkamaður" og tennur hans falli að imynd sinni.

Figure 2: Individual impact. 49-year old man with a wish for oral rehabilitation stating that he does not have any aesthetic concerns regarding his teeth because he "comes from the working class" and the teeth matches this notion.

Nýlegar heimildir gefa til kynna að einstaklingar í Skandinavíu hafi almennt góđa munnheilsu, lægstu tíðni tannleysis og flestar nýtanlegar tennur (20 tennur eða fleiri) í Evrópu $(8,9)$. Hins vegar kemur einnig fram að mestan ójöfnuð á munnheilsu í Evrópu milli pjóðfélagshópa er að finna i skandínavísku velferðarríkjunum (8-10). Ójöfnuðurinn er einkar mikill í Danmörku og jafnvel meiri en í mörgum fátækari Evrópulöndum t.d. í Eistlandi og Slóveníu $(8,10)$.

Pessi ójöfnuður sýnir að einstaklingar í viðkvæmri félagslegri stöðu eru sérstaklega útsettir fyrir slæma munnheilsu og tannleysi. Sýnt hefur verið fram á að slæm munnheilsa pessa hóps hefur slæm áhrif á lífsgæði peirra, smánun og hindranir í félagslegum samskiptum og par með hindranir í félagslegri endurhæfingu, p.m.t. í atvinnumálum $(5,11)$. Ljóst er að uppbygging tanna getur stutt einstakling í félagslegri endurhæfingu.

\section{Langvinnir verkir í munni og andliti}

Almennt eru langvinnir verkir algengt og umtalsvert heilbrigðisvandamál sem hefur áhrif á a.m.k. 20\% einstaklinga (12). Í dag eru langvinnir verkir sjálfstæð sjúkdómsgreining (13). Langvinnir verkir valda pjáningu, skertu heilsufari og lakari lífsgæðum (12). Peir hafa einnig í för með sér umtalsverðan samfélagslegan kostnað vegna skertrar starfsgetu og mikils álags á heilbrigðiskerfið. Samkvæmt The Swedish Council on Health Technology Assessment er áætlað að heildarsamfélagslegur kostnaður i Svípjóð vegna langvinnra verkja sé yfir 80 milljarðar sænskra króna á ári.

Verkir í munni og andliti eru priðja algengasta orsök 
langvinnra verkja og eru TMD verkir algengasta orsök langvinnra verkja sem ekki tengjast tönnum (14). TMD er regnhlífarhugtak sem nær yfir verki og aðra kvilla í kjálkalið (TMJ), tyggingarvöðvum og aðliggjandi svæðum. TMD verkir eru sjaldgæfir hjá börnum, á unglingsaldri eykst algengið í 8-10\% og hjá fullorðnum er pað 10-15\% $(12,14)$. Verkir í munni og andliti eru afar vangreindir $(15,16)$. Stúlkur og konur pjást oftar af verkjum í munni og andliti samanborið við drengi og karla. Auk pess hafa slíkir verkir á unglingsárum forspárgildi á verki á fullorðinsaldri (17), sem sýnir mikilvægi pess að koma í veg fyrir próun langvinnra verkja á unglingsárum. Samkvæmt niðurstöðum OPPERA-verkefnisins (Orofacial Pain Prospective Evaluation and Risk Assessment) var árlegt nýgengi meðal fullorðinna með TMD verki 3,5\% (18).

Beina parf augum til tveggja pátta pegar meta á félagsleg og samfélagsleg áhrif á langvinna TMD verki. Til dæmis er hægt að draga pá ályktun að atvinnuleysi, slök félagsleg og fjárhagsleg geta, almennt slæmt heilsufar og erfiðleikar að taka virkan pátt í samfélaginu séu pættir sem hafa áhrif á TMD verki. Á hinn bóginn geta langvinnir verkir valdið atvinnumissi, tekjutapi og aukið félagslega einangrun. Flestar rannsóknir hafa notast við tilfellamiðaða aðferðafræði, sem gerir að verkum að ekki er hægt að fullyrða hvort félagslegir pættir geti verið áhættupættir hvað varðar TMD verki, eða hvort peir eru viðbragð við langvarandi TMD verkjum. Af peim sökum er grundvallaratriði að nota aðeins framskyggnar hóprannsóknir til að rannsaka félagslega áhættupætti fyrir TMD verki.

Árið 2007 birtu Linda LeResche og félagar (19) framskyggna langsniðsferilrannsókn til að greina áhættupætti fyrir TMD verki hjá unglingum (Tafla 1). Félagslýðfræðilegir pættir á borð við kyn, kynpátt, menntun foreldra og hjúskaparstöðu foreldra voru greindir, auk annarra áhættupátta. Fjölpáttagreining leiddi í ljós að stúlkur voru líklegri til að fá greiningu á TMD verkjum Hins vegar tengdist minni menntun foreldra minni líkum á greiningu á verkjum vegna TMD.

Auknar líkur á TMD verkjum hjá börnum og unglingum komu fram hjá peim sem voru i skóla i dreifbýli, áttu föđur með minna en 9 ára skólagöngu, mátu fjárhagsstöðu fjölskyldu sinnar slæma og bjuggu ekki með fjölskyldu sinni (tafla 1) $(20,21)$.

Árið 2001 birtist kerfisbundin rýni faraldsfræðilegra rannsókna á verkjum í munni og andliti hjá fullorðnum. Niðurstöður umræddra rannsókna á tengsl fjölskyldugerðar, starfs, menntunar og fjárhagsstöðu við TMD verki voru ekki afgerandi (22) Höfundar telja pörf á frekari rannsóknum með hæfilega stórum rannsóknarhópum, par sem hægt er að greina félagsfræðilega og lífsstílstengda pætti. Höfundarnir mæltu með pversniðsrannsóknum og framskyggnri eftirfylgni.

Tafla 1. Félagslýðfræðilegir pættir tengdir verkjum vegna kjálkakvilla.

\begin{tabular}{|c|c|c|}
\hline & Börn / unglingar & Fullorðnir \\
\hline \multicolumn{3}{|l|}{ Áhættupættir } \\
\hline \multirow[t]{4}{*}{ mikil áhætta } & \multirow[t]{4}{*}{ Stúlkur (19) } & Konur (18) \\
\hline & & Hærri aldur innan aldursbilsins 18-44 ára $(18,23)$ \\
\hline & & Bandaríkjamenn af afrískum uppruna $(18,23)$ \\
\hline & & Evilöng búseta í Bandaríkjunum (23) \\
\hline lítil áhætta & Lágt menntunarstig foreldra (19) & \\
\hline \multirow{8}{*}{$\begin{array}{l}\text { Pættir sem tengjast } \\
\text { auknum verkjum vegna } \\
\text { kjálkakvilla }\end{array}$} & Skólar í dreifbýli (20) & Búseta í sveit (53) \\
\hline & Skólaganga föður styttri en 9 ár (20) & Verkamenn (54) \\
\hline & Einstaklingar sem meta fjölskyldu sína sem „fátæka” (20) & Konur (23-25) \\
\hline & Einstaklingar sem ekki búa með fjölskyldu sinni (20) & Býr ein(n) (23) \\
\hline & $\begin{array}{l}\text { Fær ókeypis hádegisverð i yfir 50\% tilvika (e. free lunch } \\
\text { program) }\end{array}$ & Verri fjárhagsstaða (23) \\
\hline & \multirow[t]{3}{*}{ Hátt menntunarstig foreldra (21) } & 20 til 50 ára (24) \\
\hline & & Innflytjendur (24) \\
\hline & & Lakari lífsgæði (OHIP-14) (24) \\
\hline
\end{tabular}


Árið 2011 birti OPPERA niðurstöður úr fyrstu tilfellamiðuðu rannsókninni á félagslegum afleiðingum langvinnra TMD verkja hjá fullorðnum. Rannsóknin sýndi fram á að konur voru i meiri hættu á TMD verkjum (23). Hærri aldur, ævilöng búseta í Bandaríkjunum og minni ánægja með efnislega stöðu spáðu fyrir um hærra algengi TMD verkja. Á óvart kom að enginn munur var á nýgengi TMD verkja milli karla og kvenna.

Sumar rannsóknir hafa sýnt fram á fylgni milli kvenna og TMD verkja (tafla 1) (24-26). Rannsókn Yekkalam og fél. (2014) (24) sýndi fram á tengsl milli TMD verkja og verri fjárhagsstöðu og pað að búa ein(n). Einstaklingar á milli 20 og 50 ára voru líklegri til að greina frá TMD verkjum (25). Rannsóknin sýndi einnig fram á umtalsverðan breytileika í algengi TMD verkja meðal innflytjenda, í sumum tilfellum mjög hátt hlutfall. pví er hægt að velta fyrir sér hvort staða innflytjenda sem slík geti verið áhættupáttur. Innflytjendur purfa að takast á við nýja siði, venjur, tungumál og gildi, sem gæti haft í för með sér aukið næmi fyrir verkjum. Auk pess er hugsanlegt að innflytjendur upplifi langvinna streitu vegna samfélagsstöðu sinnar og getu til að takast á við verki. Frekari rannsókna er pörf til að skera úr um hvort staða innflytjenda geti flokkast sem áhættupáttur, bæði hvað varðar TMD verki sem og verki almennt.

TMD verkir virðast tengjast OHRQoL á margvíslegan hátt. Líkamlegir og sálrænir pættir, auk félagslegrar virkni og upplifunar á velsæld, gætu lækkað OHRQoL (27). Kerfisbundin rýni á lífsgæðum sjúklinga með TMD leiddi í ljós að OHRQoL lækkaði í hlutfalli við TMD verki (28). Nýlega hefur komið í ljós að há OHIP-gildi tengjast TMD verkjum fullorðinna $(25,29)$. Rannsóknir sýna einnig fram á aðrar afleiðingar en áhrif TMD verkja á OHRQoL. Hjá börnum og unglingum komu félagslegar og atferlislegar afleiðingar TMD verkja fram í aukinni verkjalyfjanotkun og fjarveru frá skóla (30). Petta hafði einnig áhrif á félags- og tilfinningalíf peirra (31). Margir unglinganna lýstu preytutilfinningu, peir hættu í tómstundum, hittu vini sjaldnar og höfðu áhyggjur af framtíðinni. Pessar afleiðingar hafa áhrif á einstaklinginn, proska hans og menntun, en einnig á fjölskyldu hans og kostnað fyrir samfélagið.

Afleiðingar verkja eru flóknar í sálfélagslegum skilningi og par spila margir pættir inn í, m.a. skynrænir pættir. Sállíffræðileg líkön lýsa pví hvernig langvinnir verkir hafa áhrif á sjúkling á premur ólíkum sviðum: líffræðilegum, sálrænum og félagslegum. Dæmi um líffræðilegar afleiðingar eru breytingar á skynjun, ósjálfráđri líkamsstarfssemi og verkjadreifingu. Á sálræna sviðinu valda langvinnir verkir oft punglyndi, kvíða, svefnvandamálum og áhrifum á vitræna starfsemi (32-34). Fyrir marga sjúklinga eru verstu afleiðingarnar á félagslega sviðinu; félagsleg einangrun frá fjölskyldu og vinum, veikindaleyfi og fjárhagsvandræði (35), ásamt peim áhrifum sem koma fram á tilfinningalega og vitræna pættinum.

\section{Endurhæfing með tanngervum}

Félagslega viðkvæmir einstaklingar standa frammi fyrir mörgum og margpættum vandamálum, sem afar erfitt er að flokka í einsleitan hóp. Til að koma peim aftur út í samfélagið parf að styðjast við heildræna, samfellda og samræmda áætlun um endurhæfingu $(36,37)$. Tannlæknismeðferð getur verið mikilvæg og ætti að grípa til við gerð einstaklingsbundinnar áætlunar.

pó gögn skorti hvað varðar áhrif ólíkra tanngervalausna á lífsgæði er tannlæknismeðferð almennt talin hafa jákvæð áhrif (38). Aðlögunarerfiðleikar geta verið til staðar vegna lausra tanngerva sem einnig geta tengst ópægindum í munni (39) og neikvæðri sýn á eigin félagslega stöðu $(3,40)$. Ígræði og föst tanngervi geta skilað svipuðum árangri en reynast oftast góð lausn (41), en eru dýrari. Til að ná markmiðum tannlæknismeðferðar parf að horfa til fleiri pátta. Pannig væri hægt að halda pví fram að föst tanngervi væru ekki raunhæfur eða æskilegur kostur peirra sem eru
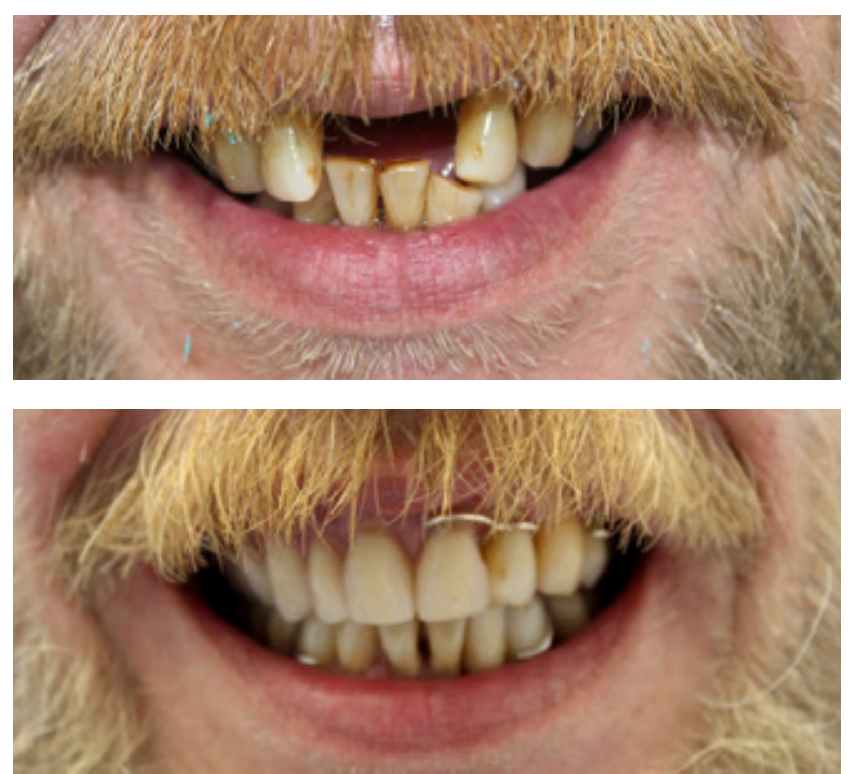

Fig. 3 A. Félagsleg endurhæfing. 54 ára heimilislaus karl með pörf fyrir uppbyggingu tanna segir að tannleysið hafi áhrif á sjálftraust og atvinnumöguleika. B. Eftir meðferð með lausum tanngervum segist hann ekki hafa nein útlitsleg vandamál.

Fig. 3. A. 54-year old homeless man in need of oral rehabilitation stating he feels the lacking teeth affects his self-esteem and is a barrier for employment. B. After oral rehabilitation with removable prosthesis. The man states he no longer have any aesthetic concerns. 
viðkvæmastir félagslega, t.d. hjá heimilislausum. Sýnt hefur verið fram á að fremur einföld meðferð, s.s. tannfyllingar og tanngervi úr akrýl, geti bætt lífsgæði pessara einstaklinga (42). Dæmi um heimilislausan einstakling eftir vel heppnaða tannlæknismeðferð er sýnt á Myndum 3. Fyrir meðferð sagðist hann hafa haft lítið sjálfstraust vegna tannleysis og hann væri viss um að auðveldara yrði að sækja um vinnu. Hann var afar ánægður með útlitið og sjálfstraust hans jókst.

Auk pess að hafa jákvæð áhrif á lífsgæði sjúklinga getur tannlæknismeðferð einnig haft i för með sér samfélagslegan ávinning, s.s. jákvæð áhrif á atvinnustöðu, minni notkun á heilbrigðiskerfi, og samfélagslegs sparnaðar. Fáar gagnlegar rannsóknir hafa beinst að áhrifum tannlæknismeðferðar á atvinnustöðu og notkun heilbrigðiskerfis hefur ekki verið rannsökuð. Rannsóknir á atvinnustöðu voru allar gallaðar aðferðafræðilega vegna skorts á samanburðarhópi, valskekkja og óvissar skilgreiningar tannlæknismeðferðar og atvinnustöðu. Niðurstöður eru nokkuð mótsagnakenndar pó flestar peirra bendi til að tannlæknismeðferð hafi jákvæð áhrif (43-45). Í dönsku verkefni var almenn félagsleg endurhæfing sem einnig innihélt tannlæknismeðferð tekin til rannsóknar. Samkvæmt henni var tímasetning meðferðar afar mikilvæg. Hún ætti að fara fram eftir að leyst hefur verið úr brýnustu nauðsynjum, s.s. búsetu og fjárhagsstöðu og pegar einstaklingur stefnir inn á vinnumarkaðinn (44). Hver áhrif tannlækismeðferðar á atvinnustöðu og notkunar á heilbrigðiskerfinu eru nákvæmlega og hvort pessi nálgun er kostnaðarhagkvæm er ekki fullljós.

Stærsta vandamál tannlæknismeðferðar hjá félagslega viðkvæmum einstaklingum er að fá pá til að mæta hjá tannlækni. Sú staðreynd að í löndum Skandinavíu purfa notendur pjónustunnar að greiða fyrir tannlæknismeðferð er hindrun. Í Danmörku hafa tvær aðferðir verið innleiddar til að leysa úr pessu. Frá 2013 geta félagslega viðkvæmir einstaklingar sótt um styrki hjá sveitarfélögum. Petta kerfi hefur ekki skilað góðum árangri og árið 2017 höfðu aðeins 14\% peirra sem rétt höfðu á styrkjum sótt um fjárstuðning (46). Hins vegar hafa verið stofnaðar nokkrar tannlæknastofur sem byggja á sjálfboðaliðastarfi og bjóða upp á gjaldfrjálsar tannlækningar fyrir pá sem eru viðkvæmastir félagslega (42).

Jafnvel pó meðferðarúrræði séu niðurgreidd eða gjaldfrjáls eru viðkvæmustu einstaklingarnir oft ófærir um að sækja sér tannlæknispjónustu, sem sýnir hversu mikilvægt er að leita að fyrra bragði til peirra (47). Auk pess parf áherslan að vera á félagslega tannlæknispjónustu sem er óháð tekjum. pað getur reynst erfitt að standa við bókaða tíma hjá tannlækni og fylla út umsóknareyðublöð pegar peir eru á sama tíma að fást við mörg önnur vandamál sem tengjast félagslegri stöðu og heilsufari. Af peim sökum er einkarekna tannlæknakerfið sérstaklega erfitt fyrir félagslega viðkvæma einstaklinga. Til að bregðast við pessu veittu dönsk yfirvöld 40-60 milljónir danskra króna fjárveitingu til að útvega peim sem viðkvæmastir eru félagslega gjaldfrjálsar tannlækningar og par með að innleiða félagslega tannlæknapjónustu í sveitarfélögunum (48). Рað blasir við að rannsaka purfi áhrifin af pessari nýju nálgun.

\section{Íhlutanir vegna tmd verkja}

Allir hafa rétt á sambærilegri meðferð, burtséð frá aldri, kyni, félagsstöðu, stöðu innan almannatryggingakerfis og pjóðerni. Hins vegar ríkir enn ójöfnuður í skipulagningu pjónustunnar hvað varðar úrræði, áunnin réttindi, hefðir og gildi. pessi ójöfnuður hefur skaðleg áhrif á heilsu milljóna einstaklinga sem pjást af langvinnum verkjum, ekki síst stúlkur og konur. pegar á unglingsaldri greina stúlkur frá meiri verkjum en piltar og verkir á fullorðinsaldri eru algengari hjá konum. Auk pess hafa konur og karlar ólíkar væntingar og upplifun af meðferð vegna hefða og gilda sem tengjast heilsufari, en petta flækir allt skipulag heilsueflingar. Algengi verkja er einnig ójafnt pegar borið er saman við menningarlega fjölbreytni. Sýnt hefur verið fram á aukið algengi TMD verkja meðal innflytjenda i syðstu hlutum Svípjóðar (25). Hægt er að líta á pennan hóp sem viðkvæman félagslega og fjárhagslega, bví eftirsókn hans á meðferð markast af pekkingu og viðhorfum hans til heilsu. Sú staðreynd að í löndum Skandinavíu purfa notendur pjónustunnar að greiða fyrir meðferð á verkjum vegna TMD er hindrun. Innan sænska heilbrigðiskerfisins er hægt að fá greiningu og meðferð við TMD verkjum sem ekki tengjast tannheilsu án greiðslu. Á mörgum svæðum í Svípjóð eru reglurnar hins vegar túlkaðar með ólíkum hætti sem hefur í för með sér ójöfnuð kostnaðar sjúklinga.

Markmið meðferðar TMD verkja er að draga úr eða koma í veg fyrir verki, endurheimta eðlilega virkni kjálka og fyrri lífsgæði og draga úr meðferðarpörf til framtíðar. Slík meðferð ætti að vera kostnaðarhagkvæm og gæti falið í sér atferlismeðferð, sjúkrapjálfun, hjálpartæki og lyf. Pó margir ólíkir faghópar fáist við sjúklinga með verki i munni og andliti eru pað oftast almennir tannlæknar sem sjá um meðferð pessara sjúklinga. Tannlæknar eru hins vegar oft óöruggir pegar kemur að greiningu pessara sjúklinga (49) og verkir í munni og andliti eru verulega vangreindir og vanmeðhöndlaðir $(15,16,50)$. Meðferðarpörf metin með meta-analysu er um 16\% hjá fullorðnum með TMD einkenni, sem er sambærilegt við algengi slíkra verkja hjá fullorðnum (51). 
Mælt hefur verið með ólíkum meðferðarúrræðum, sem hægt er að veita eina og sér eða saman. Nokkrar rannsóknir hafa leitt i ljós að sjúklingar með TMD verki upplifa bata í gegnum blöndu af meðferðum án inngrips, s.s. fræðslu, góðri sjálfsumhirðu, hugrænni atferlismeðferð, sjúkrapjálfun, lyfjameðferð og bitskinnum. Landsbundnar viðmiðunarreglur veita yfirvöldum stuðning og auðvelda peim að úthluta fjármagni í samræmi við parfir pannig að sem mestum ávinningi sé náð (52). Viðmiðunarreglurnar byggja á peirri staðreynd að mikil pörf sé á leiðbeiningum og stuðningi en mælast til pess að innan heilbrigðis- og félagspjónustu ætti að verja meira fjármagni á sumum sviðum en öðrum. Meira fjármagn ætti að setja í sjúkdóma og inngrip sem eru alvarleg en lítið eða ekkert fjármagn í vandamál sem eru síður alvarleg. Tannlæknar í Svípjóð eiga að fara eftir landsbundnum viðmiðunarreglum pegar kemur að meðferð tiltekinna kjálkaliðsvandamála en viðmiðunarreglurnar eru ítarlegar og nákvæmar. Mælt er með meðferðarúrræðum án inngrips vegna TMD verkja án sérstakra undirgreininga s.s. fræðslu, góðri sjálfsumhirðu, hugrænni atferlismeðferð, teygjum, sjúkrapjálfun og bitskinnum.

\section{Niðurstaða}

Tanntap og TMD verkir geta haft mjög neikvæð áhrif á lif einstaklings og leitt til félagslegra áskorana sem aftur geta leitt af sér neikvæð samfélags áhrif. Greinilegur ójöfnuður ríkir, sérstaklega hvað varðar tanntap og verki í munni og andliti og félagslega viơkvæmir einstaklingar eru í sérstökum áhættuhópi. Tannlæknismeðferð getur bætt lífsgæði sjúklinga sem pjást af pessum kvillum en viðkvæmir hópar purfa pó að fást við ýmsar hindranir og óljóst hvort og hvernig meðferðin hefur samfélagsleg áhrif.

\section{Heimildir}

1. Glick M Williams DM, Kleinman DV et al. A new definition for oral health developed by the FDI World Dental Federation opens the door to a universal definition of oral health. Int Dent J 2016;66:322-4.

2. Haag DG, Peres KG, Balasubramanian M et al. Oral Conditions and Health-Related Quality of Life: A Systematic Review. J Dent Res 2017;96:864-74.

3. Nordenram G, Davidson T, Gynther $G$ al. Qualitative studies of patients' perceptions of loss of teeth, the edentulous state and prosthetic rehabilitation: a systematic review with meta-synthesis. Acta Odontol Scand 2013;71:937-51.

4. Gerritsen AE, Allen PF, Witter DJ et al. Tooth loss and oral health-related quality of life: a systematic review and meta-analysis. Health Qual Life Outcomes 2010;8:126.

5. Øzhayat EB, Åkerman S, Lundegren N et al. Patients' experience of partial tooth loss and expectations to treatment: a qualitative study in Danish and Swedish patients. J Oral Rehabil 2016;43:180-9.

6. Brondani MA, MacEntee MI. Thirty years of portraying oral health through models: what have we accomplished in oral health-related quality of life research? Qual Life Res 2014;23:1087-96.

7. Øzhayat EB. Influence of self-esteem and negative affectivity on oral health-related quality of life in patients with partial tooth loss. Community Dent Oral Epidemiol 2013;41:466-72
8. Shen J, Listl S. Investigating social inequalities in older adults' dentition and the role of dental service use in 14 European countries. Eur J Health Econ 2018;19:45-57.

9. Guarnizo-Herreño CC, Watt RG, Pikhart $\mathrm{H}$ et al. Socioeconomic inequalities in oral health in different European welfare state regimes. J Epidemiol Community Health 2013:67:728-35.

10. Guarnizo-Herreño CC, Watt RG, Garzón-Orjuela N et al. Explaining oral health inequalities in European welfare state regimes: The role of health behaviours. Community Dent Oral Epidemiol 2019;47:40-8.

11. Hall JP, Chapman SL, Kurth NK. Poor oral health as an obstacle to employment for Medicaid beneficiaries with disabilities. J Public Health Dent 2013;73:79-82.

12. Breivik H, Collett B, Ventafridda V et al. Survey of chronic pain in Europe: prevalence, impact on daily life and treatment. Eur J Pain 2006;10:287-333.

13. Nicholas M, Vlaeyen JWS, Rief $W$ et al. The IASP classification of chronic pain for ICD-11: chronic primary pain. Pain 2019;160:28-37.

14. Von Korff M, Dworkin SF, Le Resche L et al. An epidemiologic comparison of pain complaints. Pain 1988;32:173-83.

15. Nilsson IM, List T, Drangsholt M. Prevalence of temporomandibular pain and subsequent dental treatment in Swedish adolescents. J Orofac Pain 2005;19:144-50.

16. Lövgren A, Marklund S, Visscher $\mathrm{CM}$ et al. Outcome of three screening questions for temporomandibular disorders (3Q/TMD) on clinical decision-making. J Oral Rehabil 2017;44:573-9.

17. Brattberg G. Do pain problems in young school children persist into early adulthood? A 13-year follow-up. Eur J Pain 2004;8:187-99.

18. Slade GD, Bair E, Greenspan JD et al. Signs and symptoms of first-onset of TMD and sociodemographic predictors of its development: The OPPERA cohort study. Pain 2013;14 (Supp 12):T20-32.

19. LeResche L, Mancl LA, Drangsholt MT et al. Predictors of onset of facial pain and temporomandibular disorders in early adolescence. Pain 2007;129:269-78.

20. Hongxing L, Astrøm N, List T et al. Prevalence of temporomandibular disorder pain in Chinese adolescents compared to an age-matched Swedish population. J Oral Rehabil 2016;43:241-8.

21. Simangwa LD, Åstrøm AN, Johansson A et al. Oral diseases and sociodemographic factors in adolescents living in Maasai population areas of Tanzania: a cross-sectional study. BMC Oral Health 2018;18:200.

22. Macfarlane TV, Glenny AM, Worthington HV. Systematic review of population-based epidemiological studies of oro-facial pain. J Dent 2001;29:451-67.

23. Slade GD, Bair E, By K et al. Study methods, recruitment, sociodemographic findings, and demographic representativeness in the OPPERA study. Pain 2011;12 (Supp 11):T12-26.

24. Yekkalam N, Wänman A. Association between craniomandibular disorders, sociodemographic factors and sel-perceived general and oral health in an adult population. Acta Odontol Scand 2014:72:1054-65.

25. Gillborg S, Åkerman S, Lundegren $\mathrm{N}$ et al. Temporomandibular disorder pain and related factors in an adult population: A cross-sectional study in southern Sweden. J Orol Facial Pain Headache 2017;31:37-45.

26. Jussila P, Knuutila J, Salmela $S$ et al. Association of risk factors with temporomandibular disorders in the northern Finland birth cohort 1966. Acta Odontol Scand 2018;76:525-9

27. Miettinen O, Lahti S, Sipilä K. Psychosocial aspects of temporomandibular disorders and oral health-related quality-of-life. Acta Odontol Scand. 2012;70:331-6.

28. Dahlström L, Carlsson GE. Temporomandibular disorders and oral health-related quality of life. A systematic review. Acta Odontol Scand 2010;68:80-5.

29. Bäck K, Hakeberg M, Wide U et al. Orofacial pain and its relationship with oral healthrelated quality of life and psychological distress in middle-aged women. Acta Odontol Scand 2020;78:74-80.

30. Nilsson IM, Drangsholt M, List T. Impact of tempromandibular disorders pain in adolescents. J Orofac Pain 2009;23:115-22.

31. Nilsson IM, List T, Willman A. Adolescents with temporomandibular disorder pain-the living with TMD pain phenomenon. J Orofac Pain 2011;25:107-16.

32. Fillingim RB, Ohrbach R, Greenspan JD et al. Psychological factors associated with development of TMD: the OPPERA prospective cohort study. J Pain 2013;14 (Supp 12):T75-90.

33. Turk DC, Fillingim RB, Ohrbach R et al. Assessment of Psychosocial and Functional Impact of Chronic Pain. J Pain 2016;17 (Supp 9):T21-49

34. WHO. Study protocol for the World Health Organization project to develop a Quality of Life assessment instrument (WHOQOL). Qual Life Res 1993:2:153-9. 
35. Sessle BJ. The Societal, political, educational, scientific and clinical context of orofacial pain. Í: Sessle BJ, ritstj. Orofacial pain. Recent advances in assessment, management and understanding of mechanisms. 1. útg. Washington DC: IASP Press, 2014:1-15.

36. Sabariego C, Coenen M, Ito $\mathrm{E}$ et al. Effectiveness of Integration and Re-Integration into Work Strategies for Persons with Chronic Conditions: A Systematic Review of European Strategies. Int J Environ Res Public Health 2018;15:E552.

37. ARBEJDSMARKED REKRUTTERING. Viden om effekter af indsatser for ledige og andre personer på overførselsindkomster. (Sótt i mars 2020). Sótt af: URL: https:// star.dk/media/5687/star-2018d-viden-om-effekter-af-indsatser-for-ledige-og-andrepersoner-paa-overfoerelsesindkomster.pdf

38. STATENS BEREDNING FÖR MEDICINSK UTVÄRDERING. Tandförluster. En systematisk litteraturöversikt. (Sótt í mars 2020). Sótt af: URL: https://www.sbu.se/ contentassets/92aa175e9369403894843b59b2e4fce5/tandforluster_fulltext.pdf

39. Øzhayat EB, Gotfredsen K. Patient-reported effect of oral rehabilitation. J Oral Rehabil 2019;46:369-76.

40. Rosing K, Christensen LB, Øzhayat EB. Associations between tooth loss, prostheses and self-reported oral health, general health, socioeconomic position and satisfaction with life. J Oral Rehabil 2019;46:1047-54.

41. Øzhayat EB, Gotfredsen K. Patient-reported effect in patients receiving implant or tooth-supported fixed prosthesis. J Oral Rehabil 2020;47:229-34.

42. Hede $B$, Thiesen $H$, Christensen LB. A program review of a community-based oral health care program for socially vulnerable and underserved citizens in Denmark. Acta Odontol Scand 2019;77:364-70.

43. Hyde S, Satariano WA, Weintraub JA. Welfare dental intervention improves employment and quality of life. J Dent Res 2006;85:79-84.

44. Freil J, Maare L. Slutevaluering. Projekt Tandpleje for tidligere alkohol- og stofmisbrugere, Vordingborg 2016.
45. Singhal S, Mamdani M, Mitchell A et al. Dental treatment and employment outcomes among social assistance recipients in Ontario, Canada. Health Policy 2016;120:12028.

46. Klebak A. Det er en elendig lov. Tandlægebladet 2019;123:672-5

47. Goode J, Hoang H, Crocombe L. Strategies to improve access to and uptake of dental care by people experiencing homelessness in Australia: a grey literature review. Aust Health Rev. 2019:[Epub, fyrir prentun]

48. SUNDHEDS- OG ÆELDREINISTERIET. Faktaark - Tandpleje til de mest udsatte borgere. (Sótt í desember 2019). Sótt af: URL: http://sum.dk/Aktuelt/Nyheder/ Sundhedspolitik/2019/December/ /media/Filer\%20-\%20dokumenter/FL-2020/01faktaark-Tandpleje-til-socialt-udsatte.pdf

49. Tegelberg A, List $\mathrm{T}$, Wahlund $\mathrm{K}$ et al. Temporomandibular disorders in childen and adolescents: a survey of dentists'attitudes, routine, an experience. Swed Dent J 2001;25:119-27.

50. Fjellman-Wiklund A, Näsström A, Wänman A et al. Patients' perceived treatment need owing to temporomandibular disorders and perceptions of related treatment in dentistry- A mixed-methos-study. J Oral Rehabil 2019;46:792-9.

51. Al-Jundi MA, John MT, Setz JM et al. Meta-analysis of treatment need for temporomandibular disorders in adult non-patients. J Orofac Pain 2008;22:97-107.

52. SOCIALSTYRELSEN. Nationella riktlinjer för vuxentandvård 2011 - stöd för styrning och ledning. Sótt af: URL: www.socialstyrelsen.se/globalassets/sharepoint-dokument/ artikelkatalog/nationella-riktlinjer/2011-5-1.pdf

53. Inglehart MR, Patel MH, Widmalm SE et al. Self-reported TMD symptoms, oral health and quality of life of children in kindergarten through grade 5: Does gender, race, and socio-economic background matter? J Am Dent Assoc 2016;147:131-41.

Johansson A, Unell L, Carlsson GE et al. Riskfactors associated with symptoms of temporomandibular disorders in a population of 50 - and 60 -year-old subjects. J Oral Rehabil 2006; 33:473-81.

English Summary

\title{
Social and societal implications of tooth loss, TMD pain and rehabilitation hereof
}

\author{
ESBEN BOESKOV ØZHAYAT DR.ODONT, PH.D. ASSOCIATE PROFESSOR, SECTION OF PUBLIC HEALTH DENTISTRY, \\ DEPARTMENT OF ODONTOLOGY, UNIVERSITY OF COPENHAGEN, DENMARK \\ EWACARIN EKBERG, ODONT. Dd., PROFESSOR SECTION OF OROFACIAL PAIN AND JAW FUNCTION, FACULTY OF \\ ODONTOLOGY, MALMÖ UNIVERSITY, SWEDEN
}

\section{ICELANDIC DENTAL JOURNAL 2020; 38: 73-79 \\ doi: 10.33112/tann.38.1.8}

Poor oral health, as in the case of tooth loss and temporomandibular disorder (TMD) pain, can have large impact on a person's quality of life and social relations. These individual consequences can in turn be important for society, as the poor oral health can lead to general health issues, higher costs in the health care system, more absence from work, and unemployment. Inequality is a major challenge in relation to tooth loss and socially vulnerable citizens more often presents a non-functional dentition. For TMD pain, inequality in relation to socioeconomic position is less pronounced and the main issue is instead a predominant female prevalence. In socially vulnerable persons, relatively non-invasive and simple prosthetic rehabilitation can be a good treatment option and there is some indication that oral rehabilitation can help in a social rehabilitation of these citizens. For TMD pain, non-invasive treatments such as patient education, self-care, cognitive behavioral modification, stretching, and occlusal appliances are recommended.

Keywords: Oral health, quality of life, tooth loss, facial pain, socioeconomic factors Correspondence: Esben Boeskov Øzhayat, Nørre Alle 20, 2200 Copenhagen N, Denmark, eboz@sund.ku.dk 